Oh, W., and Karecki, H. (1972). Phototherapy and insensible water loss in the newborn infant. American Journal of Diseases of Children, 124, 230-232.

Oh, W., Yao, A. C., Hanson, J. S., and Lind, J. (1973). Peripheral circulatory response to phototherapy in newborn infants. Acta Paediatrica Scandinavica, 62, 49-54.

Smales, O. R. C. (1978). Simple method for measuring oxygen consumption in babies. Archives of Disease in Childhood, 53, 53-57.

Wilcoxon, F. (1945). The signed ranks test. Biometrics Bulletin, 1, 80.

Wu, P. Y. K., and Berdahl, M. (1974). Irradiance in incubaters under phototherapy lamps. Journal of Pediatrics, 84, 754-755.

O. R. C. SMales

Department of Child Health, University Hospital and Medical School, Nottingham NG7 $2 U H$.

\section{Severe arrhythmias in Coxsackievirus B3 myopericarditis}

Proven viral myopericarditis only rarely presents with life-threatening arrhythmias. This report describes the first such case with serological evidence of recent Coxsackievirus B3 infection.

\section{Case report}

A previously healthy 12-year-old girl was admitted to hospital on 6 September 1976 with a 4-day history of sore throat, shivering, malaise, occasional vomiting, and with 'fainting attacks' on the 2 preceding days. On examination she was apyrexial, blood pressure $100 / 90 \mathrm{mmHg}$, pulse 80 beats $/ \mathrm{min}$. There were no cardiac murmurs, no pericardial rub, and no signs of cardiac failure. She had slight neck stiffness. A few hours after admission she had a cardiac arrest. After resuscitation, chest $x$-ray showed marked cardiomegaly. Subsequently, multifocal ventricular ectopic beats occurred which were resistant to lignocaine and to mexiletine.

During the next 36 hours ventricular fibrillation occurred on 14 occasions. Each time it was terminated by DC defibrillation (100-200 J) but was followed by severe bradycardia ( $\leqslant 30$ beats/min) which only partially responded to atropine $0.6 \mathrm{mg}$ IV. On 9 September she became breathless and was oliguric, blood urea had risen to $23 \mathrm{mmol} / 1(138.6 \mathrm{mg} / 100 \mathrm{ml}$; see Table), and chest $x$-ray showed pulmonary oedema. At this stage she was transferred to this hospital. On examination blood pressure was $100 / 60$ $\mathrm{mmHg}$, pulse 60 beats/min (see ECG, Fig.), jugular venous pressure raised $4 \mathrm{~cm}$, liver enlarged $3 \mathrm{~cm}$. A bipolar endocardial pacing catheter was introduced via the left antecubital fossa and 'on demand' pacing was started at 90 beats/min. She was given digoxin
Table Results of clinical chemistry

\begin{tabular}{|c|c|c|c|c|c|c|}
\hline \multirow{2}{*}{$\begin{array}{l}\text { Investigation } \\
\text { (normal max) }\end{array}$} & \multicolumn{6}{|c|}{ Date: September } \\
\hline & 6 & 7 & 9 & 10 & 14 & 23 \\
\hline $\begin{array}{l}\text { Blood urea } \\
(2 \cdot 7-7 \cdot 5 \mathrm{mmol} / \mathrm{l})\end{array}$ & $13 \cdot 2$ & $18 \cdot 6$ & $23 \cdot 0$ & $11 \cdot 2$ & $9 \cdot 5$ & 3.9 \\
\hline $\begin{array}{l}\text { Alananine } \\
\text { aminotransferase } \\
(100-500 \text { nkat/1) }\end{array}$ & 2562 & 4987 & 7185 & & & \\
\hline $\begin{array}{l}\text { Aspartate } \\
\text { aminotransferase } \\
(75-400 \mathrm{nkat} / \mathrm{l})\end{array}$ & 8000 & 7935 & 6000 & & & \\
\hline $\begin{array}{l}\text { Glutamin } \\
\text { oxalotransferase } \\
(9-19 \text { IU/l) }\end{array}$ & & & & 226 & 68 & 10 \\
\hline $\begin{array}{l}\text { Glutamic } \\
\text { phosphorotransferase } \\
(5-17 \mathrm{IU} / 1)\end{array}$ & & & & 687 & 207 & 16 \\
\hline $\begin{array}{l}\text { Creatine kinase } \\
(0-117 \text { IU/1) }\end{array}$ & & & & 133 & 11 & 12 \\
\hline $\begin{array}{l}\text { Lactic dehydrogenase } \\
(115-457 \mathrm{IU} / 1)\end{array}$ & & & & 1368 & 691 & 217 \\
\hline $\begin{array}{l}\text { Alkaline phosphatase } \\
(25-103 \text { IU/1) }\end{array}$ & & 75 & & & 100 & 117 \\
\hline $\begin{array}{l}\text { Bilirubin } \\
\quad(0-22 \mu \mathrm{mol} / \mathrm{l})\end{array}$ & & 7 & & & 13 & 18 \\
\hline
\end{tabular}

Conversion: SI to traditional units-Blood urea: $1 \mathrm{mmol} / 1 \approx 6.02$ $\mathrm{mg} / 100 \mathrm{ml}$. Bilirubin: $1 \mu \mathrm{mol} / 1 \approx 0.06 \mathrm{mg} / 100 \mathrm{ml}$.

$0.125 \mathrm{mg} /$ day, phenytoin $50 \mathrm{mg}$ three times a day, prednisolone $20 \mathrm{mg}$ per day, and frusemide $40 \mathrm{mg}$ IV immediately. A urinary catheter was inserted.

Progress. Ventricular fibrillation did not recur and urinary output was satisfactory. By 14 September lung fields were radiologically normal and cardiac size was decreasing. On the 17 th, paroxysmal atrial fibrillation occurred with a ventricular rate of 130/ min. Phenytoin was stopped and Kinidin durules 1 bd started. Pulse rate was easily controlled and she was gradually mobilised. The pacemaker electrode was removed on the $23 \mathrm{rd}$. She was discharged on 4 October taking digoxin $0.125 \mathrm{mg} /$ day and Kinidin durules $1 \mathrm{bd}$. Digoxin was stopped one month later. She was seen in the outpatient clinic on 3 December; there were no abnormal physical signs but she complained of breathlessness, for example, when climbing stairs. Chest $x$-ray was normal; ECG is shown in the Fig.

Investigations. Results of clinical chemistry are shown in the Table and ECGs in the Fig. $\mathrm{Hb} 12 \mathrm{~g} / \mathrm{dl}$; white cell count $15.6 \times 10^{9} / 1$. ESR $4 \mathrm{~mm}$ in the first hour (Westergren). On 20 October echocardiography showed a small pericardial effusion.

Viral studies. On 9 September Coxsackievirus B3 neutralisation titre 32, and on the 21st, 512. Attempts to isolate the virus from stools and throat washings were unsuccessful. 
I

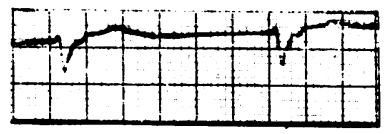

QVR
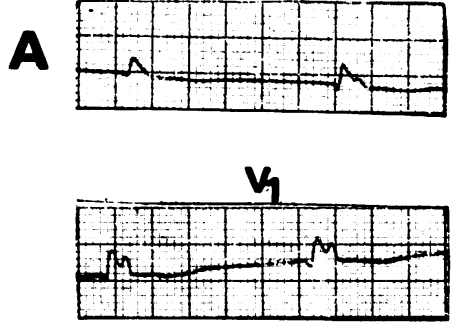

II

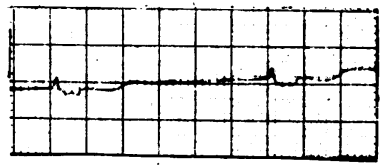

aVL

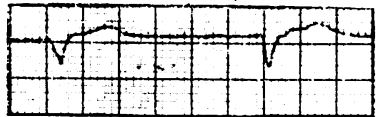

$V_{3}$

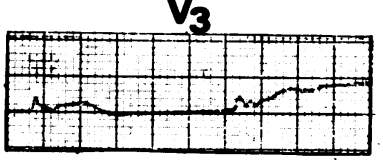

III

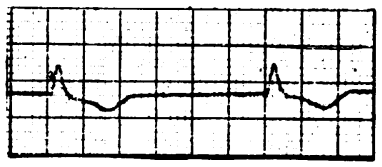

dVF

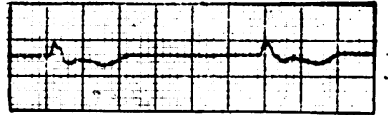

$V_{6}$

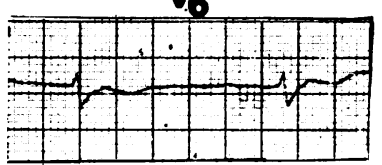

III

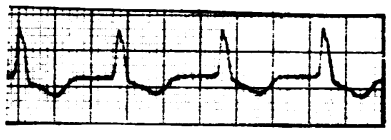

aVF

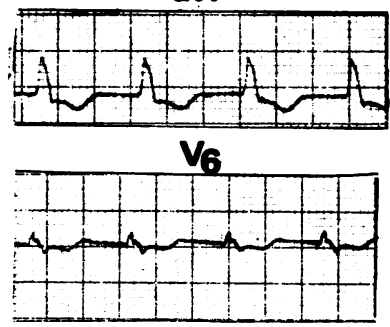

III

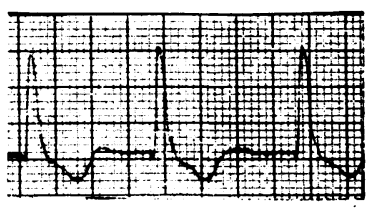

aVF
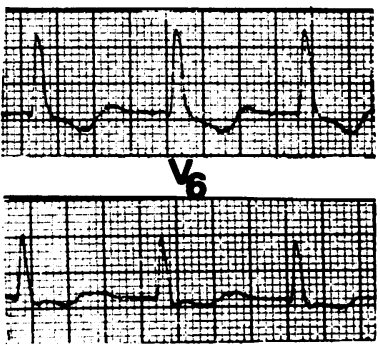

Fig. Electrocardiograms. (A) Immediately before endocardial pacing. Junctional (nodal) bradycardia-P waves can be seen deforming $S-T$ segments in $S_{2}$. Right bundle branch block and left posterior hemiblock (QRS axis approximately $\left.+140^{\circ}\right)$. (B) Next day. Changes in $V_{1}-V_{3}$ very suggestive of septal myocardial infarction. (C) 2 months after discharge from hospital. Rhythm: junctional or 1st degree $A-V$ block. $P$ waves visible at end of $T$ wave in $V_{1} . P-R$ interval 340 ms. Right bundle branch block and left posterior hemiblock still present. 
Chest $x$-rays. On 9 September showed cardiomegaly, globular heart, changes in lung fields suggesting cardiac failure. On 16 September cardiomegaly, lung fields clear. On 5 November heart size at upper limit of normal.

\section{Discussion}

This patient had features of acute myopericarditis coexistent with evidence of Coxsackievirus B3 infection. This association has previously been described but several features of this case are unusual.

Patients with viral myopericarditis usually present with chest pain or dyspnoea and have clinical features caused by pericarditis, pericardial effusion, or cardiac failure secondary to myocarditis. In contrast, this patient presented with syncope-in retrospect StokesAdams attacks - and the clinical course was dominated by life-threatening arrhythmias. This resembles in some respects the description by Lim et al. (1975) of 10 patients with myocarditis, although with the exception of one case associated with adenovirus infection they were unable to prove a viral aetiology. All their patients were young, and most were female. They presented with syncope and heart block requiring temporary endocardial pacing in 9 cases. However, ventricular fibrillation was not a major problem in these patients; it occurred in only one case and another had ventricular tachycardia. With the exception of one patient with persistent heart block all recovered fully.

Bradycardia, usually sinus, is common in viral myocarditis especially when caused by influenza (Verel et al., 1976). Atrioventricular block has also been described. Isolated case reports have documented the use of temporary endocardial pacing in myocarditis caused by 3 viruses: mumps (Thompson and Nolan, 1966), Coxsackievirus B2 (Gould et al., 1972), and adenovirus (Lim et al., 1975)-and other clinically similar cases have been described which lacked evidence of a viral aetiology. Junctional (nodal) bradycardia, which caused the patient's slow heart rate, seems to be uncommon in viral myopericarditis. The intraventricular conduction defect was also unusual; right bundle branch block with left posterior hemiblock has only twice been described in suspected viral myopericarditis (Forfang and Lippestad, 1974; Lim et al., 1975). The present case is the first in which a virus has been identified.

The reported incidence of raised serum enzyme levels in viral myopericarditis varies from $14 \%$ (Smith, 1970) to $64 \%$ (Sainani et al., 1968) and is usually slight. In this patient the levels were markedly raised. The cause of raised serum enzyme levels in myopericarditis is disputed; it is usually attributed to myocardial damage or to hepatic congestion (Colt- man, 1962). An additional factor in this case was repeated DC defibrillation. However, the presence of a marked rise in enzyme levels in the first blood sample (before defibrillation) and the absence of any additional evidence of liver dysfunction suggests that in this case extensive myocardial damage was the major source of the enzymes.

\section{References}

Coltman, C. A., Jr. (1962). Influenza myocarditis. Journal of the American Medical Association, 180, 204-208.

Forfang, K., and Lippestad, C. T. (1974). Transient left posterior hemi-block in acute myocarditis. Journal of Electrocardiology, 7, 83-85.

Gould, L., Diaz, R., and Gomprecht, R. (1972). Complete heart block in myocarditis-recovery with a pacemaker. Chest, 62, 230-233.

Lim, C-H., Toh, C. C. S., Chia, B-L., and Low, L-P. (1975). Stokes-Adams attacks due to acute non-specific myocarditis. American Heart Journal, 90, 172-178.

Sainani, G. S., Krompotic, E., and Slodki, S. J. (1968). Adult heart disease due to the Coxsackie virus $B$ infection. Medicine, 47, 133-147.

Smith, W. (1970). Coxsackie B myopericarditis in adults. American Heart Journal, 80, 34-46.

Thompson, W. M., Jr., and Nolan, T. B. (1966). Atrioventricular dissociation associated with Adams-Stokes syndrome presumably due to mumps myocarditis. Journal of Pediatrics, 68, 601-607.

Verel, D., Warrack, A. J. W., Potter, C. W., Ward, C., and Rickards, D. F. (1976). Observations on the $A_{2}$ England influenza epidemic. American Heart Journal, 92, 290-296.

\section{CHRISTOPHER WARD}

Cardio-Thoracic Unit, Northern General Hospital, Sheffield S5 7AU.

\section{Improved tube for nasojejunal feeding in low birthweight infants}

In the last few years nasojejunal infusion of milk formulas has been widely used for the feeding of low birthweight infants. The techniques of transpyloric intubation previously described are those of Rhea and Kilby (1970) and Cheek and Staub (1973). Besides the enthusiastic experiences of many, difficulties and complications relating to both methods of intubation have been encountered (Boros and Reynolds, 1974; Chen and Wong, 1974; Van Callie and Powell, 1975). Modifications of the original methods have been made by Rhea et al. (1973) and Loo et al. (1974). We describe a simple and improved tube for nasojejunal feeding by which we have successfully fed 47 infants with weights below $2000 \mathrm{~g}$.

\section{Methods}

Transpyloric intubation was carried out by means of a silicone rubber tube $0.76 \times 1.65 \mathrm{~mm}$ (Silastic Dow- 